\title{
Storage Sites in Seeds of Caesalpinia echinata and C. ferrea (Leguminosae) with Considerations on Nutrients Flow
}

\author{
Simone de Pádua Teixeira ${ }^{1}$ and Sílvia Rodrigues Machado ${ }^{2}$ \\ ${ }^{I}$ Departamento de Ciências Farmacêuticas; Faculdade de Ciências Farmacêuticas de Ribeirão Preto; Universidade \\ de São Paulo; spadua@fcfrp.usp.br; 14040-903; Ribeirão Preto - SP - Brasil. ${ }^{2}$ Departamento de Botânica; Instituto \\ de Biociências; Universidade Estadual Paulista; 18618-000; Botucatu - SP - Brasil
}

\begin{abstract}
The seeds of Caesalpinia echinata and C. ferrea behaved as typical endospermic seeds, despite their different morphological classification (exendospermic seeds were described for $C$. echinata and endospermic seeds for $C$. ferrea). Then, the aim of this work was to compare, under ultrastructural and histochemical terms, the nature of the storage substances and their accumulation sites, as well as the nutrient flow in seeds of these species. Cotyledons in C. echinata accumulate carbohydrates, lipids and proteins, which are mobilized from the outer to the inner parts as revealed by the position of plasmodesmata. Endosperm in C. ferrea accumulates carbohydrates and in C. echinata accumulates substances during the initial embryogenic phases. Such tissue develops a chalazal haustorium that is responsible for the transport of substances into the endosperm itself and from it into the embryo, confirmed by the presence of transference cells.
\end{abstract}

Key words: Cotyledon, embryo, endosperm, histochemistry, reserve substances, ultrastructure

\section{INTRODUCTION}

The accumulation of storage in seeds is one of the most important post-fertilization events. Growth, embryo differentiation and seed germination depend upon the breakdown of lipids, carbohydrates and proteins. Higher the nutrient supplies in the seed, better will be the chances for the seedlings to get established more vigorously (Kozlowski and Gunn, 1972). Lipids occur as oily bodies in the endosperm and embryo. Carbohydrates are stored either as starch grains or hemicellulosic wall thickening, which are common in the endosperm and cotyledons. Proteins occur as proteic bodies in the embryo and endosperm and build a matrix differentiated by the presence of certain minerals (Bhatnagar and Sawhney, 1981; Boesewinkel and Bouman, 1984).

Other tissues, such as seed coat, can stack storage substances in the mature seed as well as during the first embryogenic phases (Boesewinkel and Bouman, 1984). Seeds can reveal growth substances such as auxines, cytokines and gibberellins, besides carbohydrates, lipids and proteins, which are stored in the endosperm. This shows that embryonary growth and differentiation are controlled by such tissue (Vijayaraghavan and Prabhakar, 1984).

In most plants, endosperm persists until seed maturation and becomes a storage tissue (endospermic or albuminous seeds), but it can be completely absorbed throughout the embryogenesis (exendospermic or exalbuminous

\footnotetext{
${ }^{*}$ Author for correspondence
} 
seeds) (Johri et al., 1992). In exendospermic seeds, both embryo and endosperm development happens at the same time, and embryo growth occurs because of the endosperm that absorbs nutrients from the embryo sac. Storage substances of the mature seed are present in the cotyledons that have their photosynthetic activity transferred to other tissues. In endospermic seeds, embryo growth is limited and begins long after endosperm grows. Endosperm is not thoroughly consumed and is responsible for storage until germination; cotyledons, which are foliaceous in this case, will synthesize nutrients after they emerge from the soil (Kozlowski and Gunn, 1972; Boesewinkel and Bouman, 1984; Johri et al., 1992; Richards, 1997). The genus Caesalpinia s. $l$. (Leguminosae, Caesalpinioideae) presents species that show both seed kinds. Therefore, it was chosen for the present study. In a former study on the ontogenesis of the seeds of $C$. echinata Lam. (brazilwood) and C. ferrea Mart. ex Tul. var. ferrea (brazilian ironwood), embryos of $C$. echinata (exendospermic seeds) presented a resting phase, even with a complete absorption of the endosperm during the embryogenesis, similarly to what happened with $C$. ferrea (endospermic seeds), i.e., the seeds of both species behave as endospermic seeds (Teixeira et al., 2004). Such observations brought other comparative questions into consideration and discussed in the present article: Which kind of storage substances can be found in seeds? Which are the tissues that really present a storage function in seeds? How does the nutrient flow happen inside seeds? These questions are considered here under both histochemical and ultrastructural points of view and aim to contribute with the knowledge on the germination of seeds and establishment of seedlings. Moreover, according to Borges et al. (2005), the analysis of storage substances in embryo could contribute to understand the process of seedlings development from seeds at different stages of maturation. Our data also intend to favor the conservation of species under extinction risk and found in highly advanced degradation ecosystems, such as the brasil wood tree of the Atlantic Rainforest.

\section{MATERIAL AND METHODS}

\section{Studied species}

Caesalpinia echinata and C. ferrea var. ferrea are two Brazilian tree species that occur preferentially in the northeastern Atlantic rainforest (Polhill and Vidal, 1981). C. echinata has been almost exterminated as a result of its use as a source of red dye for fabrics and ink and the current total size of natural stands of this species is low (Cardoso et al., 1998). C. ferrea, a species used in Brazilian folk medicine, has been investigated for its pharmacological properties (Carvalho et al., 1996; Nakamura et al., 2002a, b).

\section{Plant material}

Samples of $C$. echinata were collected during the spring of 2001 from six plants cultivated in Campinas (22 $\left.54^{\prime} \mathrm{S}-47^{\circ} 06^{\prime} \mathrm{W}\right)$ and on the Fazenda

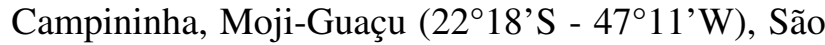
Paulo state, Brazil. The C. ferrea samples were collected from five plants cultivated in Campinas $\left(22^{\circ} 54^{\prime} \mathrm{S}-4^{\circ} 06^{\prime} \mathrm{W}\right)$ and Botucatu (22 ${ }^{\circ} 52^{\prime} \mathrm{S}-$ $\left.48^{\circ} 30^{\prime} \mathrm{W}\right)$, São Paulo state, Brazil, during the summer and autumn of 2002. Voucher specimens were deposited in the herbarium of the Universidade Estadual de Campinas (UEC), São Paulo state, Brazil, under the accession numbers 26368 and 51731 for C. echinata and 60661 and 66698 for $C$. ferrea.

Seeds were taken from $C$. echinata fruits $(66.5 \mathrm{~mm}$ and $80.0 \mathrm{~mm}$ long) and C. ferrea fruits $(55.0 \mathrm{~mm}$ and $75.0 \mathrm{~mm}$ long). At least five seeds were collected at each stage of maturity per individual per species. Seeds inside shorter fruits presented embryos that started to protrude cotyledons (immature seeds) and those ones inside longer fruits presented embryos with completely expanded cotyledons (mature seeds), according to Teixeira et al. (2004).

\section{Ultrastructure}

For ultrastructural studies, small pieces of imature and mature seeds were fixed immediately after harvest with Karnovsky's solution $(0.075 \mathrm{M}$ in phosphate buffer, $\mathrm{pH}$ 7.2-7.4, for $4 \mathrm{~h}$ ) (Karnovsky, 1965), postfixed with osmium tetroxide ( $1 \%$ in the same buffer for $1 \mathrm{~h}$ ), dehydrated in an acetate series and embedded in Araldite. Ultrathin sections were stained with $2 \%$ uranyl acetate for 15 min (Watson, 1958) and with lead citrate for 15 min (Reynolds, 1963) and then examined using a Philips EM 301 electron microscope. 


\section{Histochemical tests}

Histochemical studies were carried out on the imature and mature seeds, which were fixed immediately after harvest, embedded in paraffin, sectioned $(8-10 \mu \mathrm{m})$ and mounted in synthetic resin. To detect lipids, material were fixed in buffered formalin and stained with Sudan Black B (Jensen, 1962) and Nile Blue (O'Brien and McCully, 1981). To detect proteins and polysaccharides, material were fixed in FAA 50 (formalin: acetic acid: alcohol 50\%), and stained with Aniline Blue Black (Fisher, 1968) and PAS Reagent (O’Brien and McCully, 1981), respectively. Standard control procedures were carried out simultaneously. Photomicrographs were taken using a Leica model DM 4500 microscope.

\section{RESULTS}

Both immature and mature seeds were given the descriptions mentioned above; no differences in tissue types were observed.

\section{Ultrastructure}

Epidermal and parenchymatic cells of $C$. echinata cotyledons (Fig. 1) presented thick walls stained with PAS reagent and numerous plasmodesmata (Figs 1, 5). In the epidermal cells, plasmodesmata occurred in the anticlinal walls (Fig. 1), whereas in the parenchimatic cells plasmodesmata occurred in the anticlinal and periclinal walls. The nucleus was central and spherical in the epidermal cells (Fig. 1 ), but lobed in the subepidermal cells, with a conspicuous nucleolus (Fig. 3). The cytoplasm was abundant and electron-dense, rich in free ribosomes, globular mitochondriae with welldeveloped cristae and plastids with ellipsoid starch grains (Figs 2, 4, 6). Rough endoplasmic reticulum and protein bodies were distributed sparsely in the cytoplasm. Numerous electron-opaque oil bodies were concentrated near the cell wall (Figs 1, 2, 5); in the subepidermal cells, they were also found around plastids (Figs 3, 4). A larger quantity of plastids containing starch grains (Fig. 4) was found in the central cotyledonal cells. Cells of the hypocotyl-radicle axis differed from cotyledonal cells because of their trapezoidal nucleus (Fig. 7) and lack of endoplasmic reticulum. Uncertain organelles containing a thin granular matrix, as well as strongly electron-dense material undergoing degradation were found in the cytoplasm of the cotyledons (Fig. 4) and of the hypocotyl-radicle cells (Figs 7, 8).

In $C$. ferrea, the mycropilar endosperm cells had lobate nucleus with a prominent nucleolus (Fig. 9), a dense mitochondria-rich cytoplasm, endoplasmic reticulum, plastids with an electron-dense matrix, oil drops, plastids containing starch grains and hyperactive dictyosomes (Figs 10, 12). The cell wall stained with PAS reagent, became thick towards the embryo and formed numerous ingrowths inside the cell (Figs 10, 11). These kind of cell was only reported in $C$. ferrea mycropilar endosperm (compare figs 23, 24). The chalazal endosperm cells had thick PAS-positive walls with numerous plasmodesmata (Fig. 13); their cytoplasm was rich in plastids containing starch grains and oil droplets, mitochondriae, rough endoplasmic reticulum and dictyosomes (Figs 1416). The remaining nucellar cells had vacuoles and cytoplasm containing mitochondriae, extensive rough endoplasmic reticulum, plastids containing oil droplets, and dictyosomes (Fig. 17). They were connected with the endosperm cells (Fig. 18) by numerous plasmodesmata.

\section{Histochemical tests}

Results confirmed that the main storage seed sites were the cotyledons in $C$. echinata and the endosperm in $C$. ferrea (Table 1). The storage substances found in the cotyledons of $C$. echinata were acid and saturated lipids (Figs. 1-6, 19), proteins (Fig. 20), starch grains (Fig. 4), and neutral polysaccharides. The endosperm of $C$. ferrea contained acid polysaccharides (Fig. 22) and starch grains (Fig. 12), and became gelatinous when hydrated. The foliar cotyledons of $C$. ferrea accumulated starch grains (Fig. 21) and numerous chloroplasts; the cell walls were made of neutral polysaccharides (Fig. 21).

\section{DISCUSSION}

Results found in the present work partly corroborated the hypothesis that had been proposed by Kozlowski and Gunn (1972). The main seed storage tissues were the cotyledons in C. echinata and the endosperm in C. ferrea, and that was expected for exendospermic and endospermic seeds, respectively (Boesewinkel and Bouman, 1984; Johri et al., 1992; Richards, 1997). 
However, endosperm in $C$. echinata also accumulated substances throughout seed development and the photosynthesizing embryo in $C$. ferrea also accumulated starch grains. Moreover, endosperm, in both the species, presented mitochondriae with developed cristae, well-developed dictyosomes and rough endoplasmic reticulum, organelles that were commonly found in synthesizing tissues and substance conveyors (Bhatnagar and Sawhney, 1981). The beginning of the embryogenesis of these two species coincided with the beginning of the endosperm action towards the transport of substances and the development of an aggressive chalazal haustorium that went into nucellar cells up to the inner tegument cells (Teixeira et al., 2004), as well as labyrinth wall cells in C. ferrea. The labyrinth wall cells found in the mycropilar region of the endosperm in C. ferrea corresponded to the transference cells cited by Gunning and Pate (1969). According to DeWitt et al. (1999) and Thompson et al. (2001), the number of folds in such cell walls is responsible for the increasing of plasmalema surfaces and leads to the transport of solutes in the seeds.

In Leguminosae, labyrinth wall cells were observed in the inner layers of the seed testa and in the cotyledon epidermis of the seeds in Vicia faba (Talbot et al., 2001; Thompson et al., 2001) and not in the endosperm, as in C. ferrea. Before germination, the position of the labyrinth face in the cell showed that in the mature seeds of $C$. ferrea, the transport of nutrients was polarized towards the embryo, which was confirmed by the presence of a large amount of starch grains in the embryonary tissue. Still, the hydrophilic contents (acid and neutral polysaccharides) of the endospermic cells that were persistent in $C$. ferrea must be related to seed soaking and its resistant testa allowed the seed to remain in soil during several months (Lorenzi, 1998).

In $C$. echinata, the nutrient flow inside seeds occurred mainly through plasmodesmata, once transference cells were not observed. The cotyledon epidermic cells contacted both the nucellar cells (immature seed) and the other cotyledon, and embryonary axis cells through plasmodesmata. The final accumulator tissue, mainly starch, was made of cells from the cotyledon central region and showed that the substance mobilization got started from the outer parts.

Table 1 - Histochemical tests employed in the storage sites in seeds of Caesalpinia echinata and C. ferrea (The symbol + indicates positive reaction, i. e., presence of storage substance in seed sites, and the symbol - indicates negative reaction; * seed with cotyledonary stage of the embryo; after this stage the endosperm was completelly consumpted).

\begin{tabular}{|c|c|c|c|c|c|}
\hline Storage sites & Species & $\begin{array}{c}\text { Sudan Black B } \\
\text { (total lipids) }\end{array}$ & $\begin{array}{c}\text { Nile Blue } \\
\text { (acid lipids) }\end{array}$ & $\begin{array}{c}\text { Aniline Blue- } \\
\text { Black (proteins) }\end{array}$ & $\begin{array}{c}\text { PAS + Toluidine Blue } \\
\text { (polysaccharides) }\end{array}$ \\
\hline \multirow{2}{*}{ endosperm } & *C.echinata & & & & + \\
\hline & C. ferrea & - & - & - & + \\
\hline \multirow{2}{*}{ cotyledon } & C. echinata & + & + & + & + \\
\hline & C. ferrea & - & - & - & + \\
\hline \multirow{2}{*}{$\begin{array}{l}\text { Embryonary } \\
\text { axis }\end{array}$} & C. echinata & + & + & + & + \\
\hline & C. ferrea & - & - & - & + \\
\hline
\end{tabular}



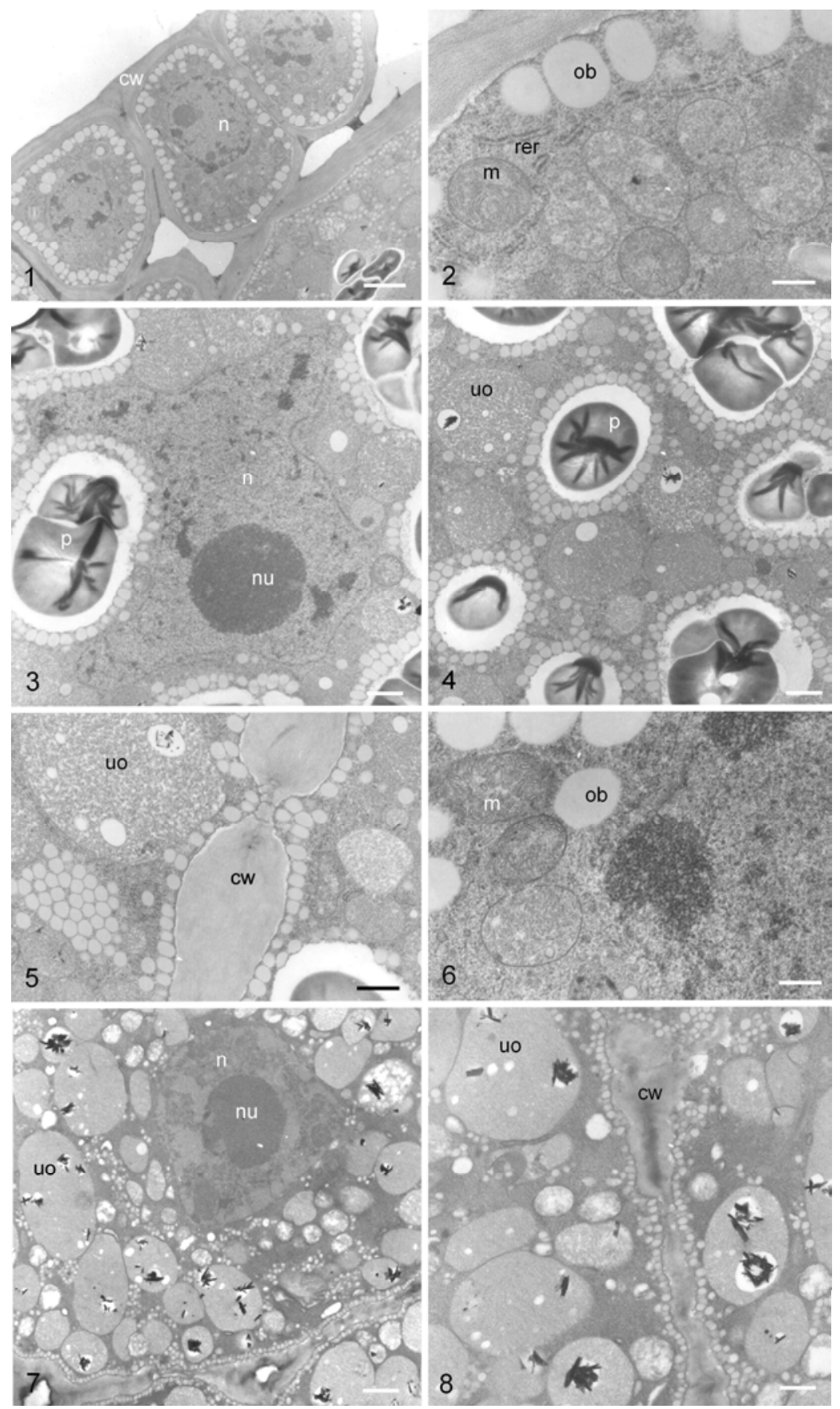

Figures 1-8 - Electron micrographs of Caesalpinia echinata mature embryo. 1-2. Epidermic cells of cotyledons. Note the central and spheric nucleus (n) and numerous oil bodies concentrated near the cell wall (cw) in 1, and the cytoplasm rich in mitochondriae $(\mathrm{m})$, oil bodies (ob), and rough endoplasmic reticula (rer) in 2. 3-6. Parenchymatic cells of cotyledons. 3. Lobed nucleus (n) with a conspicuous nucleolus (nu). 4. Cytoplasm rich in oil bodies, plastids (p) containing starch grains, and organelles (uo) containing a thin granular matrix and electron-dense material undergoing degradation. 5. Cell wall $(\mathrm{cw})$ with plasmodesmata, surrounded by numerous oil bodies and organelles containing a thin granular matrix (uo). 6. Detail of mitochondriae with well-developed cristae and of electron-opaque oil bodies. 7-8. Cells of hypocotyl-radicle axis. Note the trapezoidal nucleus (n) with a conspicuous nucleolus (nu) and the cytoplasm rich in organelles containing a thin granular matrix (uo) in 7, and plasmodesmata in the cell wall (cw) and oil bodies in 8 . Scale bars: $1,7=0.35 \mu \mathrm{m} ; 2,6=0.05 \mu \mathrm{m} ; 3,4=0.2 \mu \mathrm{m}, 5=0.15 \mu \mathrm{m} ; 8=$ $0.12 \mu \mathrm{m}$. 

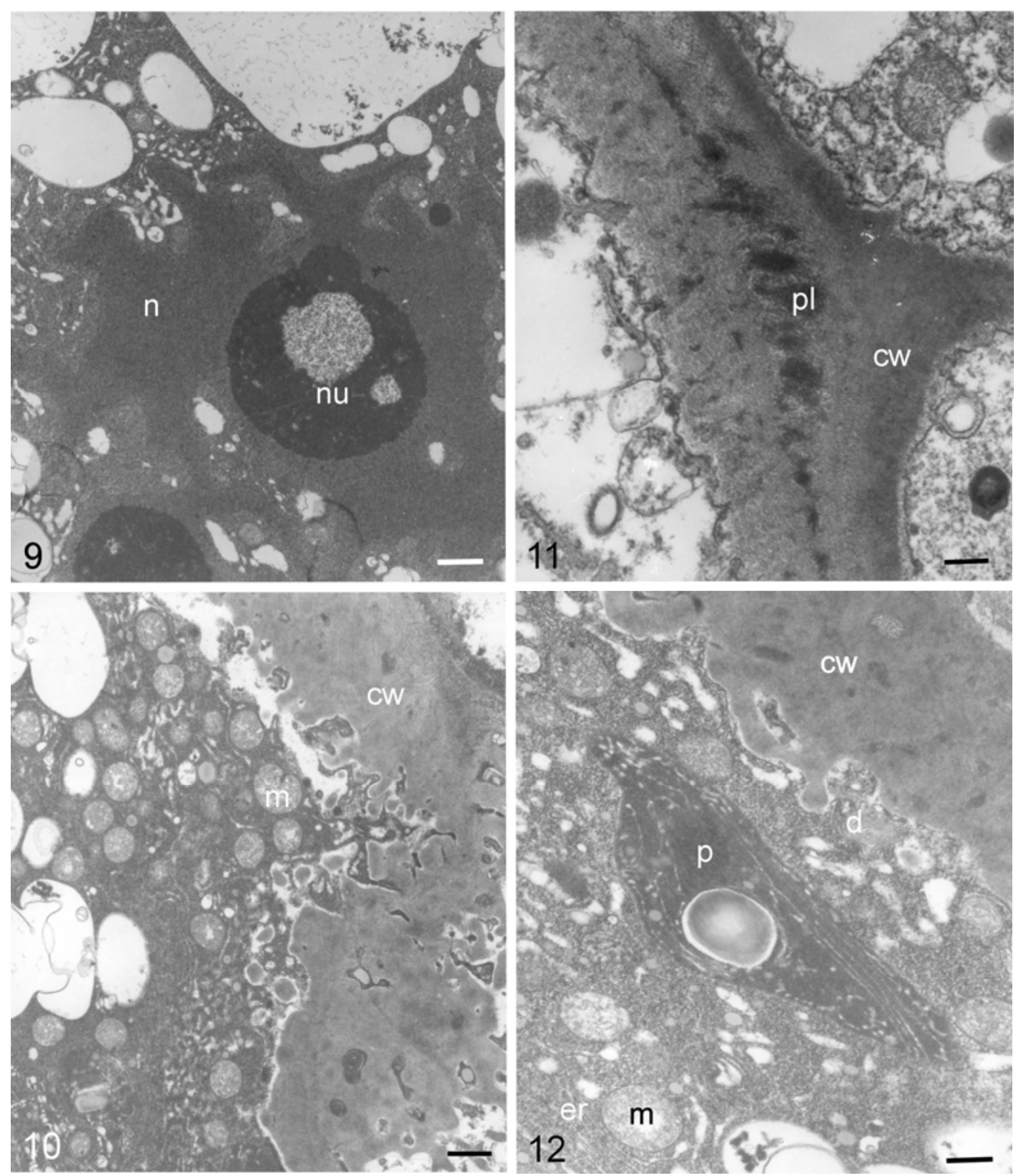

Figures 9-12 - Electron micrographs of the transfer cells of Caesalpinia ferrea mycropilar endosperm. 9. Note the lobed nucleus (n) with a conspicuous nucleolus (nu). 10. Note the cytoplasm rich in mitochondriae $(\mathrm{m})$ and the cell wall $(\mathrm{cw})$ with numerous ingrowths inside the cell. 11. Detail of the cell wall (cw) with numerous plasmodesmata (pl). 12. Cytoplasm with plastids (p) containing starch grains, mitochondriae (m), endoplasmic reticula (er) and dictyossomes (d). Scale bars: $9=1.02 \mu \mathrm{m} ; 10=0.75 \mu \mathrm{m} ; 11=0.24 \mu \mathrm{m} ; 12=0.43 \mu \mathrm{m}$. 

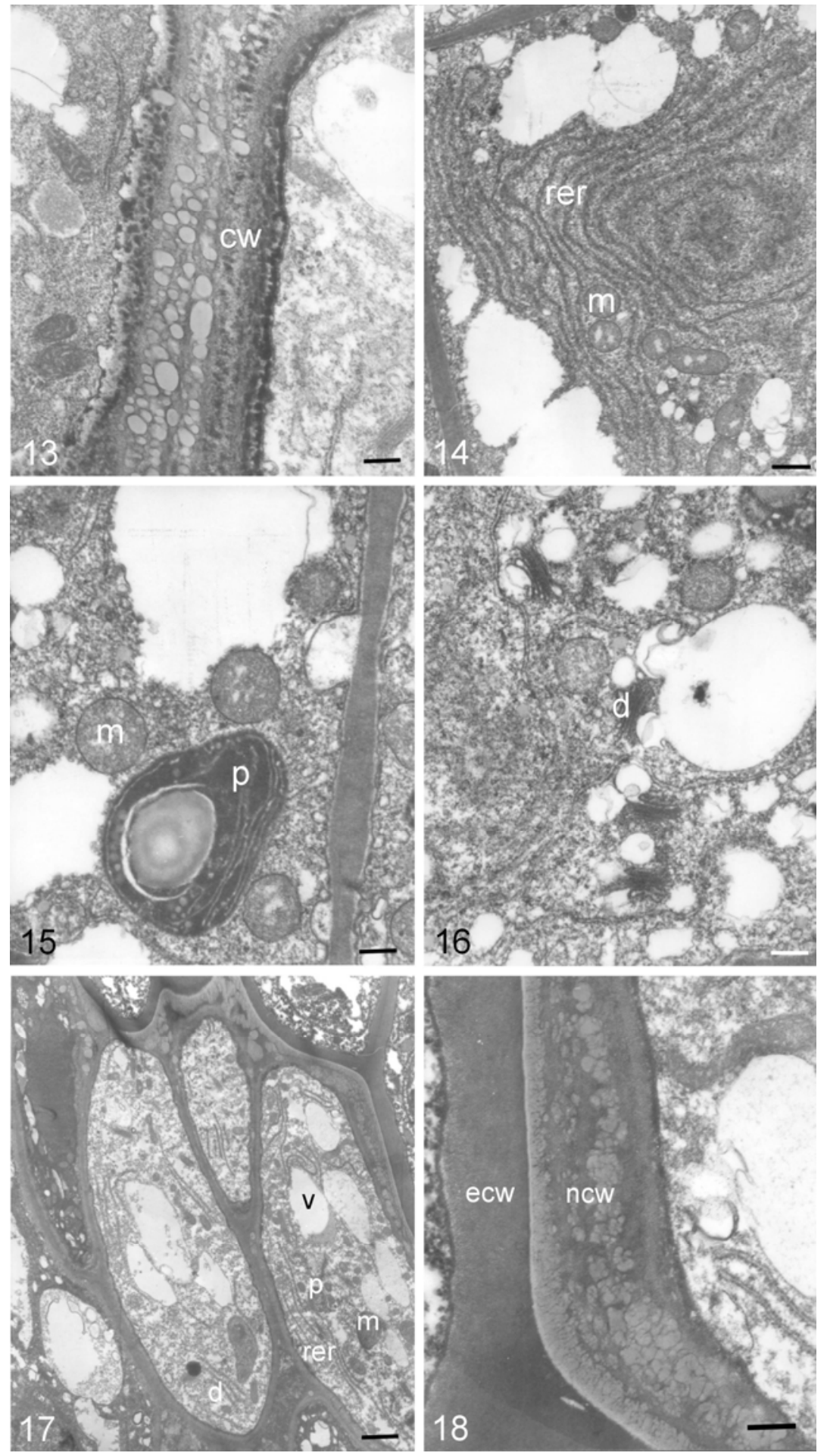

Figures 13-18 - Electron micrographs of Caesalpinia ferrea chalazal endosperm (13-16) and remaining nucellar cells (17-18). 13. Cell wall (cw) with plasmodesmata and oil droplets. 14. Cytoplasm rich in extensive rough endoplasmic reticula (rer) and mitochondriae $(\mathrm{m}) .15$. Detail of plastids (p) containing starch grains, and of mitochondriae $(\mathrm{m})$. 16. Note the numerous dictyossomes (d) in the cytoplasm and numerous vacuoles. 17. Vacuoles (v) and cytoplasm containing mitochondriae $(\mathrm{m})$, extensive rough endoplasmic reticulum (rer), plastids (p) containing oil droplets, and dictyosomes (d). 18. Cell walls of a nucellar cell (ncw) and of an endosperm cell (ecw). Scale bars: 13, 15, 16, $18=0.32 \mu \mathrm{m} ; 14=0.75 \mu \mathrm{m}$; $15=1.3 \mu \mathrm{m}$. 

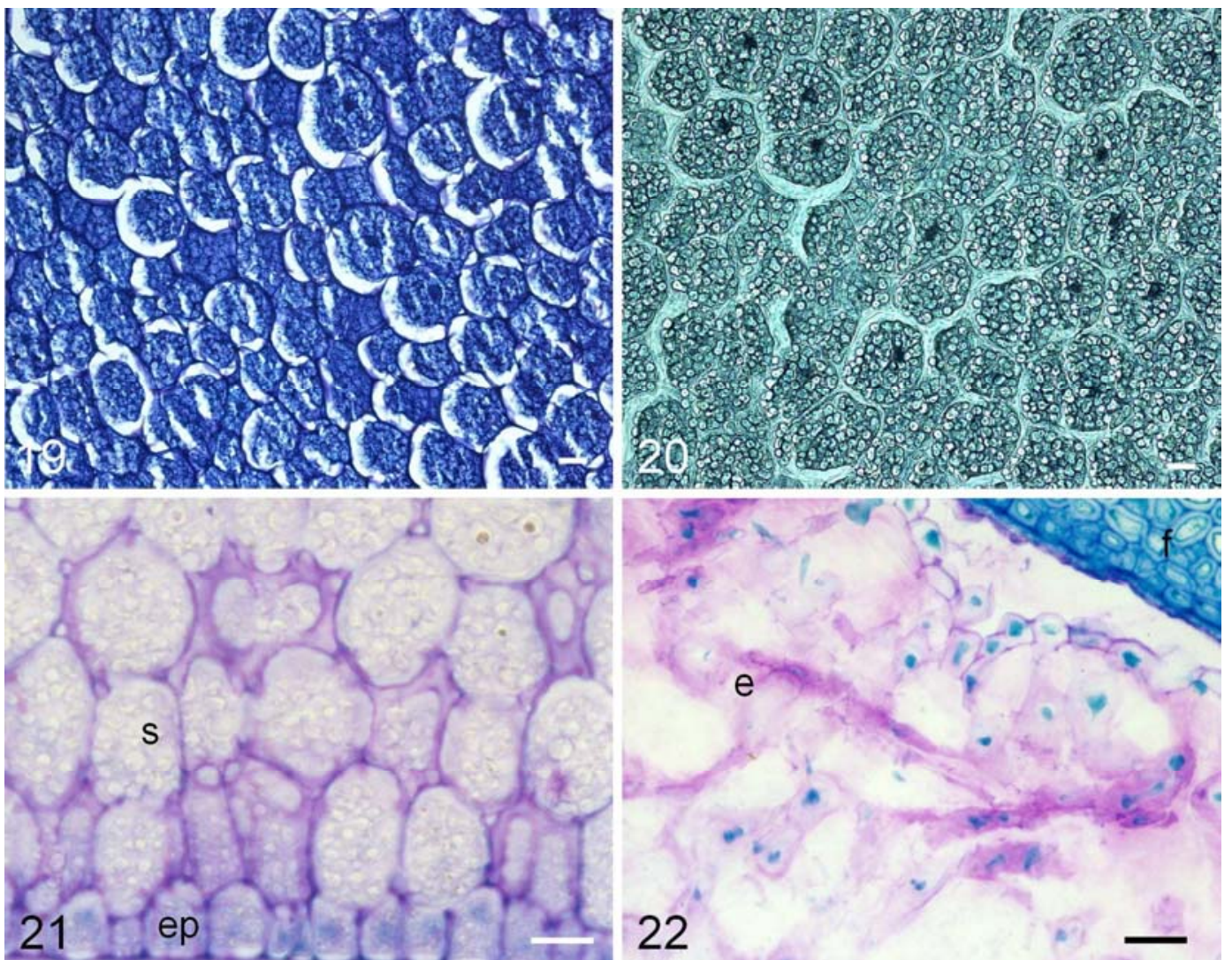

Figures 19-22 - Storage substances found in Caesalpinia echinata (19-20) and C. ferrea seed sites (21-22). 19. Cotyledonar cell contents reacted with Nile Blue indicating the presence of acid lipids. 20. Cotyledonar cell contents reacted with Aniline Blue-Black indicating the presence of proteins. 21. Epidermic (ep) and subepidermic (s) cells of cotyledons reacted with PAS Reagent and Toluidine Blue indicating the presence of starch grains in the cytoplasm and neutral polysaccharides in the cell walls. 22. Endosperm (e) reacted with Toluidine blue indicating the presence of acid polysaccharides. Scale bars: $19,20=15 \mu \mathrm{m} ; 21=22 \mu \mathrm{m} ; 22=43 \mu \mathrm{m}$.
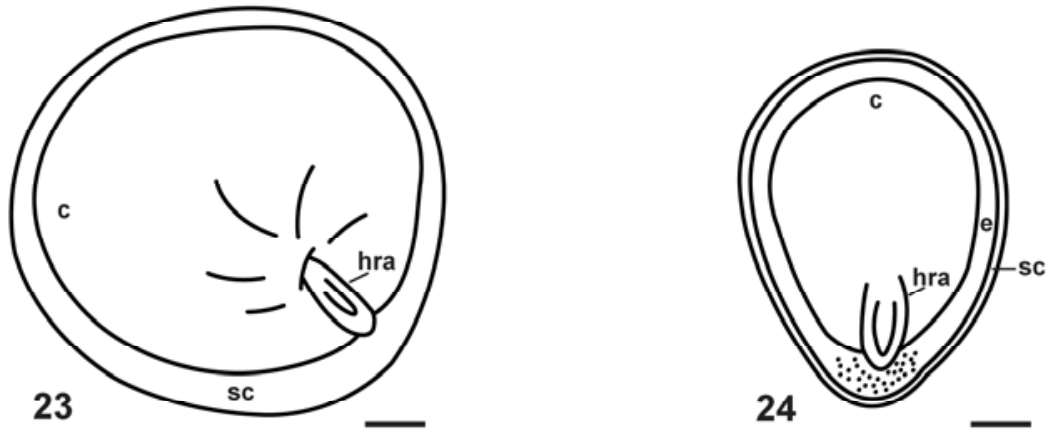

Figures 23-24 - Mature seed morphology of Caesalpinia echinata (23) and C. ferrea (24). Note the endosperm in $C$. ferrea seed containing transfer cells (dotted) in the mycropilar region. e - endosperm, c cotyledon, hra - hypocotyl-radicle axis, sc - seed coat. Scale bars: $23=5 \mathrm{~mm} ; 24=2 \mathrm{~mm}$. 
By comparing the seeds of $C$. echinata and $C$. ferrea, more storage substances were identified in the seeds of the former species, although a big amount of starch grains was found in the seeds of both the species; such grains presented glucose which could be promptly incorporated so that metabolic energy was generated (Buckeridge et al., 2000). Ultrastructural and histochemical evidence of proteins could be found in cotyledon cells of mature seeds in $C$. echinata, which showed numerous free ribosomes, rough endoplasmic reticulum, mitochondriae with developed cristae and strongly Aniline Blue Black-stained contents in cells. According to Silva et al. (2000), proteins which were largely stored in sub cellular compartments and were not mobilized during the seed germination could be lecithins, these have been observed in the cotyledons of other species of Leguminosae, mainly Papilionoideae. Lecithins would act as defense proteins against predators and pathogens and would protect cotyledons while mobilization of the storage substances is being carried out (Cavada et al., 1993). Histophysiological studies on postgermination phases in the seeds of $C$. echinata would be necessary so that the function of the proteins observed in this work could be explained. Storage substances (neutral polysaccharides) have also been observed in the cell walls of tissues that make up the testa of seeds in both studied species. In the leguminous species, such polysaccharides have been identified as galactomanans, xiloglucans and galactans (Buckeridge et al., 2000); likewise starch, they could be the main storage carbohydrate in seeds (Buckeridge and Reid, 1996).

Finally, results presented in this work and previous seed developmental study obtained for the same species (Teixeira et al., 2004) have shown that the classification of seeds, based upon morphological data from only one development phase (usually the final phase), not always corresponded to their behavior during development. It is necessary to know ontogenesis, substances and their storage sites and the substance flow inside the seeds.

\section{RESUMO}

As sementes de Caesalpinia echinata e C. ferrea comportam-se como endospérmicas, apesar de descritas na literatura como exendospérmicas e endospérmicas, respectivamente. Desta forma, o objetivo deste trabalho foi comparar, em termos ultra-estrutural e histoquímico, a natureza das substâncias de reserva e seus tecidos acumuladores, bem como o fluxo de nutrientes nas sementes destas espécies. Os cotilédones em $C$. echinata acumulam carboidratos, lipídios e proteínas, mobilizados da periferia para o centro, como visto pelo posicionamento dos plasmodesmas. $\mathrm{O}$ endosperma em $C$. ferrea acumula carboidratos e lipídios, e em $C$. echinata, acumula substâncias nos estádios iniciais da embriogênese. Este tecido desenvolve um haustório calazal agressivo, que transporta substâncias para o endosperma propriamente dito e deste para o embrião, fato confirmado pela presença de células de transferência no endosperma.

\section{ACKNOWLEDGEMENTS}

We thank FAPESP (scholarship number 01/071241 and grant number 00/06422-4) for financial support, Cláudio José Barbedo and Rodrigo Augusto Santinelo Pereira for critically reading of the manuscript and Fernando Santiago dos Santos for English revision. The electron microscopy work was carried out at Centro de Microscopia Eletrônica of Universidade Estadual Paulista (UNESP), Botucatu, SP, Brazil.

\section{REFERENCES}

Bhatnagar, S. P. and Sawhney, V. (1981), Endosperm Its morphology, ultrastructure, and histochemistry. Int. Rev. Cytol., 73, 55-102.

Boesewinkel, F. D. and Bouman, F. (1984), The Seed: Structure. In: Johri, B. M. (Ed.). Embryology of Angiosperms. Berlin: Springer-Verlag. pp. 567-610.

Borges, I. F.; Giudice Neto, J. D.; Bilia, D. A. C.; Figueiredo-Ribeiro, R. C. L. and Barbedo, C. J. (2005), Maturation of seeds of Caesalpinia echinata Lam. (Brazilwood), an endangered leguminous tree from the Brazilian Atlantic Forest. Braz. Arch. Biol. Technol., 48, 851-861.

Buckeridge, M. S. and Reid, J. S. G. (1996), Major cell wall storage polysaccharides in legume seeds: structure, catabolism and biological functions. Ciênc. Cult., 48, 153-162. 
Buckeridge, M. S.; Santos, H. P. and Tiné, M. A. S. (2000), Mobilisation of storage cell wall polysaccharides in seeds. Pl. Physiol. Bioch., 38, 141156.

Cardoso, M. A.; Provan, J.; Powell, W.; Ferreira, P. C. G. and Oliveira, D. E. (1998), High genetic differentiation among remnant populations of the endangered Caesalpinia echinata Lam. (Leguminosae-Caesalpinioideae). Mol. Ecol., 7, 601608.

Carvalho, J. C. T.; Teixeira, J. R. M.; Souza, P. J. C.; Bastos, J. K.; Santos, D. and Sarti, S. J. (1996), Preliminary studies of analgesic and antiinflammatory properties of Caesalpinia ferrea crude extract. J. Ethnoph., 53, 175-178.

Cavada, B. S.; Moreira, R. A.; Oliveira, J. T. A. and Grangeiro, T. B. (1993), Primary structures and functions of plant lectins. Rev. Bras. Fisiol. Veg., 5, 193-201.

DeWitt, G.; Richards, J.; Mohnen, D. and Jones, A. M. (1999), Comparative compositional analysis of walls with two different morphologies: archetypical versus transfer-cell-like. Protoplasma, 209, 238-245.

Fisher, D. B. (1968), Protein staining of ribboned epon sections for light microscopy. Histochemie, 16, 9296.

Gunning, B. E. S. and Pate, J. S. (1969), "Transfer cells" - plant cells with wall ingrowths specialized in relation to short distance transport of solutes - their occurrence, structure and development. Protoplasma, 68, 107-133.

Jensen, W. A. (1962), Botanical Histochemistry: Principles and Practice. San Francisco: W. H. Freeman.

Johri, B. M.; Ambegaokar, K. B. and Srivastava, P. S. (1992), Comparative Embryology of Angiosperms 1. Berlin: Springer-Verlag.

Karnovsky, M. J. (1965), A formaldehydeglutaraldehyde fixative of high osmalarity for use in eletron microscopy. J. Cell Biol., 27, 137A-138A.

Kozlowski, T. T. and Gunn, C. R. (1972), Importance and characteristics of seeds. In: Kozlowski, T. T. (Ed.). Seed Biology - Importance, Development and Germination 1. New York and London: Academic Press. pp. 1-20.

Lorenzi, H. (1998), Árvores Brasileiras. Manual de Identificação e Cultivo de Plantas Arbóreas Nativas do Brasil 1. Nova Odessa: Instituto Plantarum de Estudos da Flora Ltda.
Nakamura, E. S.; Kurosaki, F.; Arisawa, M.; Mukainaka, T.; Takayasu, J.; Okuda, M.; Tokuda, H.; Nishino, H. and Pastore, F. (2002a), Cancer chemopreventive effects of a Brazilian folk medicine, Jucá, on in vivo two-stage skin carcinogenesis. $J$. Ethnopharmacol., 81, 135-137.

Nakamura, E. S.; Kurosaki, F.; Arisawa, M.; Mukainaka, T.; Okuda, M.; Tokuda, H.; Nishino, H. and Pastore, F. (2002b), Cancer chemopreventive effects of constituents of Caesalpinia ferrea and related compounds. Canc. Lett., 177, 119-124.

O'Brien, T. P. and Mcccully, M. E. (1981), The Study of Plant Structure. Principles and Selected Methods. Melbourne: Termarcarphy Ltd.

Polhill, R. M. and Vidal, J. E. (1981), Caesalpinieae. In: Polhill, R. M. and Raven, P. H. (Eds.). Advances in Legume Systematics 1. Kew: Royal Botanic Gardens. pp. 81-95.

Reynolds, E. S. (1963), The use of lead citrate at high $\mathrm{pH}$ as an electron-opaque stain in electron microscopy. J. Cell Biol., 17, 208.

Richards, A. J. (1997), Plant Breeding Systems. London: Allen and Unwin, $2^{\text {nd }}$ ed.

Silva, L. I. M. M.; Ramos, M. V.; Cajazeiras, J. B.; Ferreira, P. R.; Carvalho, C. A. V.; Grangeiro, T. B.; Nunes, E. P.; Sampaio, A. H.; Freitas, B. T.; Silveira, J. A. G. and Cavada, B. S. (2000), Lectins from Pisum arvense seeds behave differently from storage proteins during germination in the darkness. Rev. Bras. Fisiol. Veg., 12, 255-262.

Talbot, M. J.; Franceschi, V. R.; Mccurdy, D. W. and Offler, C. E. (2001), Wall ingrowth architecture in epidermal transfer cells of Vicia faba cotyledons. Protoplasma, 215, 191-203.

Teixeira, S. P.; Carmello-Guerreiro, S. M. and Machado, S. R. (2004), Fruit and seed ontogeny related to the seed behaviour of two tropical species of Caesalpinia (Leguminosae). Bot. J. Linn. Soc., 146, 57-70.

Thompson, R. D.; Hueros, G.; Becker, H.-A. and Maitz, M. (2001), Development and functions of seed transfer cells. Pl. Sci., 160, 775-783.

Vijayaraghavan, M. R. and Prabhakar, K. (1984), The Endosperm. In: Johri, B. M. (Ed.). Embryology of Angiosperms. Berlin: Springer-Verlag. pp. 319-376.

Watson, M. L. (1958), Staining of tissue sections for electron microscopy with heavy metals. J. Bioph. Bioch. Cytol., 4, 475. 